seed, but is the result of some electrical action producing them spontaneously. The late Duke of Portland used to say they need not sow white clover where bones were used freely; and where the pure white lime is used, clovers are seen without sowing seed. Also, if, as may be seen any season on the roads of Derbyshire, where the roads are repaired with white limestone, the clovers are present by the side of the wheel-tracks. 'The same may be seen on laying land down to permanent grass. Use farmyard manures, and the coarser grasses are seen; use roadscrapings and compost, and the finer grasses are sure to come. The charlock is an unwelcome visitor ; but its removal in corn crops is often worse than the evil itself. 'Let both grow together "till the time of harvest." The seed has more value than some suppose, and when crushed will be found a good tonic. Nothing is given to us in vain."

Comment in this case also is needless. One hardly knows which most to admire in this rich paragraph; the independence of the trammels of the ordinary rules of syntax displayed by the writer ; the teleological moral drawn at the end ; or the contempt for science manifested in the assertion of the possibility of so highly organised a plant as the charlock arising " spontaneously' in the ground. When such lamentable ignorance of the very elements of science is displayed by those who should be the leaders, what can we expect from the farmers themselves? Well may we exclaim, Qutis docebit ipsos doctores!

London, Sep. 23

ALFRED W. BeNNETT

\section{ICE FLEAS}

$\mathrm{T}^{\mathrm{He}}$ HE water flea, Daphne pulex, is a well-known inhabitant of rivers and fresh-water lakes, and, being distinctly visible to the naked eye, often attracts the attention of water drinkers. Though a harmless crustacean, this little creature not only excited great interest in parliamentary committees during the last session, but exercised a very powerful influence over the choice of a water supply for the northern capital of Great Britain. The ice flea, if known at all, is certainly less celebrated, and probably by no means likely to be so potent in its parliamentary influence; nevertheless a short account of it may not be wholly uninteresting to the readers of NATURE.

During a recent ramble upon the Morteratsch Glacier, I turned over some of the isolated stones which lie upon its surface partially imbedded in the ice ; under many of them I found hundreds of a minute jet black insect, which jumped many times its own length at a single spring, in a manner somewhat resembling the performance of a common flea.* The ice flea is about one-twelfth of an inch long. Viewed through a pocket lens, it was seen to have six leys, supporting a body obscurely jointed like that of a bee, and furnished with two jointed antennæ. The total length of the insect appeared to be about six times its thickness, the antennæ being about one-fourth as long as the body. The insects were not found under every stone, they generally occurred under flattish fragments of rock, presenting a surface of about a square foot, and having a thickness of from 2 to 4 inches. Stones of this size are sufficiently warmed by the sun's rays to melt the ice beneath them more rapidly than it is liquefied by the direct solar beams. A surface of rock absorbs luminous thermal rays better than does a surface of comparatively white ice, and it transmits these rays to the ice beneath it, partly by conduction and partly by radiation from its under surface. The stone thus melts its way an inch or two deep into the ice, forming for itself a kind of basin. Sometimes these cavities are watertight, and then any space between the stone and the walls of its basin are filled with water derived from the melting ice. Under such conditions I have never found any fleas beneath the stone. But occasionally the ice basin is drained, and it was under stones

* My friend Prof. Eschenburg, of Zürich, had previously observed these insects on the Morteratsch Glacier, and it was his verbal account of them that led me to search for them. resting in such comparatively dry basins that the insects were found. In all cases nearly the whole of the fleas were found upon the ice, very few being attached to the stones. They were grouped together in shoals, so that probably forty or fifty of them frequently rested upon a single square inch of ice. On removing the stones; the insects were very lively, but this might be owing to their sudden transition from comparative darkness to direct sunlight.

I saw no indications of food of any kind beneath the stones, indeed these insects must have a struggle for existence of a most severe character. Living in an atmosphere the temperature of which never rises above the freezing point, they must be continually exposed to inundations during the day by the stoppage of the drainage of the ice basin, whilst on clear nights severe frosts frequently threaten them with an icy grave. Again, during the day the roof of their habitation is, as it were, continually falling in upon them, and thus constantly exposing them to the risk of being crushed to death ; for, as the ice melts beneath the stone, the latter is continually changing its points of support. It may be, however, that the crystalline structure of the ice causes it to melt with a corrugated surface, which provides everywhere valleys of sufficient depth to protect the fleas from destruction by the fall of the superincumbent mass of rock. We have also not to search far for a possible source of food. The cold of the glacier benumbs and kills thousands of insects which alight upon its surface, and bees, wasps, flies, and moths are frequently seen dead upon the ice. Then there is the so-called "red snow," and other allied organisms of similar habits, which may perhaps minister to the wants of this singular insect. Is the ice flea, like its irritating cousin, a nocturnal predatory insect, and does it issue from its dangerous abode at nightfall in search of frozen bees and butterflies? Perhaps some of the entomological readers of NATURE may be already acquainted with this animal, and be able to supply further information respecting it.

E. FRANKLAND

\section{REMARKS ON PROF. WILLTAMSON'S NEW CLASSIFICATION OF THE VASCULAR CRYPTOGAMS}

T discussing the points at issue between Prof. Williamson and myself; it will be necessary for me to say a few words on stems in general, because we evidently. have very different views of the construction of stems; and until we thoroughly understand each other, it is impossible for us to come to any definite conclusions. In a young dicotyledonous stem (see Oliver's "Lessons," p. I I2, fig. 67) we find three things : a quantity of cellular tissue surrounded by an epidermis, and near the centre a series of young fibro-vascular bundles. As growth goes on, these. separate bundles coalesce and form a central cylinder of united fibro-vascular bundles. These bundles leave a portion of the cellular tissue in the middle of the stem, which becomes the pith. Outside the fibro-vascular bun. dles we have also a small quantity of the cellular tissue, but it soon becomes to a great extent inseparable from the sub-epidermal cells. Other portions of the cellular tissue remain between the united fibro-vascular bundles, and form the medullary rays. In many stems and in most roots these rays are wanting, and the cellular tissue would therefore be divided into two portions by the united bundles. Each fibro-vascular bundle consists of two portions, which are separated by a layer of cells capable of division, the cambium. On the inner side of the cambium ceils we have in general spiral vessels; porous vessels, and wood cells, while on the outer side we have the soft bast and bast fibres. The epidermis is soon thrown off in many cases, and is replaced by layers of cork-cells 
or peculiar thickened bast-fibre-like cells from underneath. The stem thus consists of three sets of tissues: (I) the limitary tissues, including epidermis, periderm, \&c. ; (2) the fibro-vascular bundles; and (3) the primitive tissue or Grundgezuebe of Sachs (see "Mo. Mic. Journal," vol, iii. p. I60). In an older dicotyledonous stem we find the limitary tissues becoming largely developed, cork-cambium and layers of cork being formed. The fibro-vascular bundles have also largely developed, the cambium cells by division, and the conversion of these new cells into permanent tissue has formed a number of annual rings of wood-cells and vessels as well as layers of bast, while the primitive tissue only increases very slowly in the medullary rays, the pith not increasing, and the primitive tissue under the epidermis becoming lost in the rapidly-developing bark. Such is the structure of a dicotyledonous stem.

In a monocotyledon we have the same tissues, limitary, fibro-vascular, and primitive. The primitive tissue is largely developed, forming the cellular tissue by which the fibro-vascular bundles are surrounded (Oliver, "Lessons," p. II3, fig. 68). These fibro-vascular bundles differ quite as much in the nature of their cells and vessels as those of the dicotyledon, often one form being developed in excess of the other. The limitary tissues also develop cork and other cells. There is thus very little difficulty in comparing a very young dicotyledonous stem with that of a monocotyledon. In the monocotyledons the fibrovascular bundles are closed, and therefore no annual layers are found; but in such stems as Dracæna, Aloe, Yucca, \&c., we have the stem increasing in diameter. The outer cells of the primitive tissue divide and form not only new primitive tissue but new fibro-vascular bundles (Sachs, "Lehrbuch der Botanik," ed. 2, p. I03, fig. 90). Prof. Williamson would probably call these Exogenous Endogens.

When we come to the Lycopod and Fern stem, we find the same parts-limitary tissues, fibro-vascular bundles, and primitive tissue. In ferns the bundles are more or less scattered, like those of the monocotyledon, while in the Lycopods we either have them separate or else all joined together to form a central axis (see Sachs, op. cit., figs. 66 and 89). Round this central axis in Lycopods we have the primitive tissue, while outside we have the epidermis often with peculiar thickened cells underneath, forming part of the limitary tissues. In Mosses, Charas, and Thallophytes we have only the primitive and limitary" tissues, the fibro-vascular bundles being entirely absent. In some of the Thallophytes, however, as in Lessonia, we may have the primitive tissue increasing just as in Dracæna.

In Lepidodendron, as in some of our modern Lycopods, we have a central axis of combined fibro-vascular bundles, and a large quantity of primitive tissue, no longer all parenchymatous, as in many of our recent Lycopods, but mostly prosenchymatous, as in L. chamcecyparissus. This primitive tissue went on increasing year after year, new cells forming by division, these being soon changed into hard prosenchymatous cells. Outside we have the limitary tissue strengthened, as in some of our recent species, by remarkable prosenchymatous cells. In Lepidodendron the primitive tissue was capable of dividing in the same way as that of Dracæna. The stem increased year after year, not by growth of the wood-cells, \&c., of the fibro-vascular bundles, as in a dicotyledonous stem, but by additions to the primitive tissue. I never denied that the Lepidodendron stem increased in diameter, but pointed out that the increase takes place by multiplication of the cells near the periphery of the primitive tissue, the portion not likely to be often preserved in Lepidodrendon stems. This mode of growth is quite compatible with the statement that the fibro-vascular bundles are closed as they are both in Ferns and Lycopods. As Prof. Williamson admits that "the large vascular cylinder of the fossil forms is a development of what is seen not only in Lyco- podium chamacyparissus, but in every one of the numerous Lycopods of which I have examined sections," there is no difficulty in settling the matter. The cylinder in L. chamacyparissus is part of the primitive tissue, not of the fibro-vascular bundles. Such being the case, the central axis of Lepidodendron is not a "vascular medulla," but a series of closed fibro-vascular bundles. In Lepidodendron we have merely a pseudo-exogenous growth taking place in the primitive tissue, while in Gymnosperms and Dicotyledons we have true exogenous growth in the fibro-vascular bundles. In Ferns this pseudo-exogenous growth is not likely to take place, as a fern produces only a few large leaves, while in a Lycopod or Lepidodrendron, which produces numerous small leaves, water for purposes of transpiration would have to be rapidly supplied in yearly increasing quantities. This is provided for by the increase which takes place in the wood-cells of the primitive tissue, not as in Dicotyledons, by additions to the wood-cells of the fibro-vascular bundles. Prof. Williamson has been led away by the mere superficial resemblance of the parts, and has never tried to understand the homologies of these stems. He has mistaken the united closed fibro-vascular bundles in the centre of the stem for a vascular medulla, i.e., for a portion of the primitive tissue ; and he has mistaken the woody cylinder surrounding this - which is a modified portion of the primitive tissue-for the united fibro-vascular bundles of a dicotyledon. After making two such fatal errors, can his proposed new classification be considered of any value?

W. R. M'NAE

\section{A NEW DYNAMETER}

T $T$ need not be said that in astronomical observation it is always desirable, to say the least of it, to have a tolerably correct estimate of the magnifying power actually in use. This has hitherto been only attainable either by means of the maker's valuation, or through the employment of the apparatus unfortunately termed a "dynameter," a word which every classical scholar would wish to see as soon as possible dismissed from circulation. The former alternative is, I am sorry to say, often far from reliable; the latter involves an outlay not within the reach of every astronomical student. The Rev. E. L. Berthon, Vicar of Romsey, Hants, well known already for many ingenious and valuable inventions, has recently devised a little apparatus for attaining the same object, which deserves high commendation. Its very moderate price places it within the reach of all; and its accuracy appears equal to that of instruments of more complicated construction and higher pretension. I have heard on excellent authority that very little dependence can be placed on the estimates of magnifying powers too frequently furnished to purchasers. Eyepieces are both constructed and rated too frequently by "rule of thumb," and their real, if measured, will be found widely different from their nominal power. Some opticians, as, for instance, the celebrated reflectormaker Short, have had an unfortunate reputation for exaggerating the power of their instruments, and without any suspicion of misrepresentation: such has been the case even at the celebrated Optical Institute of Munich, as appears by the corrections made by W. Struve in the numerical values of the Dorpat oculars, 94, I40, 2 I 4 , $320,480,600,800,1,000,1,500,2,000$, being respectively lowered by him on trial to 86, 133, I98, 254, $420,532,682,848,1,150,1,500$. In this instance, it is possible that some different mode of measurement may have led to the discrepancy. Uncertainty, it may be suspected, occasionally arises from this cause. I once undertook, at the special request of a friend, to verify with a doubleimage dynameter the power of some oculars constructed by a very eminent optician, whose name was an abundant guarantee for his good faith; but the results, on which I 